\title{
IMPACT OF CIRCULAR ECONOMY AS THE EU'S AMBITIOUS POLICY
}

\section{Urška Fric}

Faculty of Information Studies in Novo mesto, Slovenia

E-mail: urska.fric@fis.unm.si

\begin{abstract}
The article describes the role of legislative and legal framework which brought about a new approach to waste management through the concept of circular economy, and its drivers. We explicitly focus on the impact of ambitious EU environmental policy and its financial support from the European Commission (EC) which helped social actors recognize not only the ecological, but also the economic and social benefits of the circular economy. Over 50 actions under the "Circular Economy Action Plan" launched in 2015 have been delivered or are being implemented in this period in European Union (EU). Through overview of the EU'S ambitious policy, best practice of the circular economy in the world and status quo in circular economy at EU level we also show the circular economy is nowadays a crucial megatrend and there is still needed to increase up action at EU level, provide the competitive advantage it brings to EU economy and close the loop. Beside impact of ambitious EU environmental policy article focuses on the Cultural Political Economy (CPE) approach as a political economy approach with the purpose for explaining the role of legislative and legal framework as a mechanism for selection and retention of the paradigm of circular economy.
\end{abstract}

Key-words: circular economy, EC, policy, Europe 2020, Cultural Political Economy, status quo

\section{Introduction}

After 1970 - that is in the last 40 years - countries adopted a broad spectrum of environmental legislation, which can be described today as the most exhaustive modern standards compendium in the world. European Union environmental legislation - also known as environmental acquis - comprises over 500 directives, regulations, and decisions (EUR-Lex 2015).

Social actors in the global market have been increasingly trying to keep up with environmental legislation and policies of European Union (EU) for the past decade, resulting in efficient handling of primary resources through 
reuse of waste in the domain of circular economy, which is the primary subject of this article.

For the purpose of tracking and enforcement of EU's environmental policies, transformation into circular economy is financially supported predominantly from European structural and investment funds, European Fund for Strategic Investments, LIFE program and Horizon 2020 as the biggest EU Research and Innovation programme ever with nearly $€ 80$ billion of funding available over 7 years - from 2014 to 2020 (Horizon 2020 2019). In addition to the private investment this money will attract - it promises more breakthroughs, discoveries and world-firsts by taking great ideas from the lab to the market (ibid.). Horizon 2020 is the financial instrument implementing the Innovation Union, a Europe 2020 flagship initiative aimed at securing competitiveness in Europe (ibid.) where is the crucial idea of Europe 2020 precisely a strategy for smart, sustainable and inclusive growth.

This article first briefly describes the legislative and legal framework which brought about a new approach to waste management through the concept of circular economy, and its drivers. We use the concept of Ellen MacArthur Foundation $(2016,2017)$ to characterize the model of circular economy as a response to the pressures of growing economy, consumption of limited resources, and overall capacity of the environment. Afterwards, we use combining critical semiotic analysis with an evolutionary and institutional approach to political economy ofers one interesting way to achieve this goal (Jessop and Oosterlynck 2008) transformation from linear to circular ecoomy where an evolutionary and institutional approach to semiosis enables us to recognize the semiotic dimensions of political economy (ibid.). We focus on the impact of ambitious EU environmental policy and its financial support from the European Commission (EC) which helped social actors recognize not only the ecological, but also the economic and social benefits of the circular economy.

\section{Overview of the EU's ambitious Policy}

Directive on waste (2008/98/EC) proposed a completely new approach to waste handling and turning waste into raw materials and required EU members to adopt measures ensuring that as much waste as possible is reused in the future (EUR-Lex 2008). Considering the worrisome status quo related to the low proportion of waste being recycled in Europe in 2014, EU published a proposal of new legislation on recycling titled "Towards a circular economy: A zero waste programme for Europe" (EUR-Lex 2014).

Suggested amendments involved the following goals: (1) increase the 
proportion of reused and recycled municipal waste to a minimum of $70 \%$ by 2030 ; (2) increase the recycling rate for packaging waste to $80 \%$ by 2030 ; (3) ban the landfilling of recyclable waste; (4) decrease landfilling of waste food for $30 \%$ by 2025; (5) implement a system for monitoring compliance of EU members and inform EU about flaws and discrepancies in individual countries for a faster feedback; (6) ensure absolute traceability in handling of hazardous waste; (7) improve cost efficiency of extended producer responsibility schemes by setting minimum requirements for producer responsibility at EU level; (8) simplify reporting obligations for Small and Medium Enterprises (SMEs); (9) provide harmonized universal calculation of goals and improve reliability of Key Performance Indicators (KPIs); and (10) update obsolete legislative requirements to provide universal definitions (EUR-Lex 2014).

The amendment intervened with a very complex and broad legislation framework on waste management, which had been in use in the EU for previous four decades (EUR-Lex 2014). The framework directive from 2008 also introduced by-product (only applies to remains of a production process) and end-of-waste (waste flows collected from different sources and turned into raw material for industrial processes) into terminology (ibid.). The universal rules defining when a waste flow no longer has a waste status are defined on EU level through EU regulations (ibid.).

In 2015, the EC published a proposal ("Closing the loop: Commission delivers on Circular Economy Action Plan") of new legislation on decreasing waste landfilling and increasing processing for reuse and recycling of the key waste flows, such as municipal waste and packaging waste (EUR-Lex 2015). Through the goals defined in the "Circular Economy Action Plan, EU members would gradually achieve benchmarking results and encourage required investment in waste management (ibid.). The purpose of additional measures was to clarify and simplify implementation of the new policy and to support economic incentives, as well as improve extended producer responsibility schemes (ibid.).

During the same year, United Nations signed "Agenda 2030 for sustainable development containing 17 goals of sustainable development in three dimensions - economic, social, and environmental" - where the 12th goal focuses on implementing sustainable production and consumption methods (World Health Organization 2016, 2-3). The deadline for all goals is set for 2030, however the most important characteristic of this new Agenda is its universality (ibid.). Considering national specifics, its goals are attainable by all countries, whether they are developed or still in development phase (ibid.).

Two years later, the EC published a communication and working 
document titled "Strengthening Innovation in Europe's Regions: Strategies for resilient, inclusive and sustainable growth of the Commission's committees". The document described proposed development of smart specialization while tackling the following main challenges (EUR-Lex 2017): (1) boosting the innovation and competitiveness potential of European regions, as a basis for a sustainable growth model; (2) increasing interregional cooperation, which is a key element in globalised economies; (3) strengthening the focus on less developed and industrial transition regions; (4) improving and building on joint work across EU policies and programs supporting innovation.

The challenges in this communication consider different aspects environment, energy, sustainable development, and efficient resource usage - and can be integrated into the industrial policy of a certain country. In Slovenia, for the example, the smart specialization strategy is depicted in a strategical document aiming to increase investment into research, development and innovation in the areas with the highest potential to boost the economy (Ministry of Economic Development and Technology Republic of Slovenia 2013).

In 2018, the EC signed the "Circular Economy Action Plan", which involved several new strategies, measures and suggestions concerning (EC 2019): (1) managing the complete lifecycle of plastics from design to recycling for the whole EU, demanding that all plastic packaging is recyclable by 2030 . For this to happen, EU countries would have to come up with new cost-efficient and effective methods of plastic recycling, reduce plastic packaging altogether, and increase investments in this area to provide innovative approaches (ibid.). To reduce marine litter originating from the sea, the EC demanded that port receptions use oxo-degradable plastic and published a report on its impact; (2) connection between legislation on chemicals, products, and waste; (3) the framework for monitoring the progress of individual countries and EU in general, including ten KPIs for all lifecycle phases and economic aspects, such as production, consumption, waste management, jobs, and innovation; (4) 27 of the most critical materials, which the EC proposes to prioritize in circular economy, as published in "Report on Critical Raw Materials and the circular economy" (ibid.).

Further on in 2018, the EC adopted some additional ambitious initiatives (EC 2019): (1) proposal of legislation considering reducing the environmental impact of certain plastic products, which would represent the implementation phase of the EU-wide strategy for adopting circular economy on plastics. The proposal allowed different measures, such as market restrictions on single-use plastics, when alternatives are clearly available, more user-friendly labelling, raising awareness, and extended producer responsibility schemes, where 
producers were also responsible for the cost of cleaning up the litter; (2) proposal of minimum requirements regarding water reuse to ensure stable, safe, economically viable and efficient reuse of water for irrigation (ibid.). In the following, we clarify the role of circular economy for EU economy through concepts, theory and best practice examples in the world.

\section{The Circular Economy: Concepts, Theory and Examples}

Between 7000 and $3000 \mathrm{BC}$, when the main farming practices were livestock and agriculture, the population of Earth was 25 million (ra-rod 2018). After WW2, when mass industrialization set off, population grew to 5 billion and consumption of fossil fuels increased exponentially (ibid.). Today, Earth's population is well over 7 billion projections show that 9.8 billion people will be threading the Earth by 2050 (ibid.). In turn, this accelerated population expansion results in an additional increase in global demand for (natural) resources (ibid.).

As states World Wildlife Fund (2016 in De Angelis 2018), nowadays we live in an economy that is exhausting natural capital: 'by 2012, the bio-capacity equivalent of 1.6 earths was needed to provide the natural resources and services humanity consumed in that year'. Ellen MacArthur Foundation and McKinsey (2012 in de Angelis 2018) continue surely 'humanity to be better off in a capital restoring, and regenerative circular economy. But there are the following crucial questions: (1) what does such an economy look like, and exactly why do we need it, (2) who are the key players in creating and maintaining a circular economy and (3) what changes will they need to adopt for such an economy to fourish' (ibid.).

According to the report from World Economic Forum the circular economy concept and terminology has gained momentum after the 2012 World Economic Forum, where this report, prepared in collaboration with the Ellen MacArthur Foundation and McKinsey \& Company, showed for the first time its convenience and the way to drive a new economic development (World Economic Forum in Barbero 2017, 9). 'However, popularity very often carries disadvantages or risk as, for example, becoming just a buzzword - some people affirm the true substance of circular economy is lost in translation and is misunderstood', states Barbero $(2017,9)$. 'There are many misconceotions of circular economy such as that it is just another way of describing recycling, or that it encourages people to re-use and keep products for a longer time, therefore it decreases sales since it might be an opportunity for some people, but on the long term will have a negative impact on manufacturers, and so on', also 
explains Barbero $(2017,9)$. That is not the case this chapter aims to clarify the role of circular economy through concepts, theory and examples.

Circular economy represents the EU's way of dealing with the pressures of growing economies and consumption on limited resources and environmental capacity as one of its most highly developed concepts (Ellen MacArthur Foundation 2016, 2017). The metamorphosis into circular economy is therefore based on re-use, adaptation, and processing of existing materials and products (ibid.). In order to minimize waste production, it also allows for using more renewable energy sources, discontinuing hazardous chemicals, cutting down on raw material, and reinventing product design to make it more recyclable and still retain its added value for as long as possible (ibid.). In circular economy, products remain in the environment even after they have reached the end of their lifespan (ibid.).

To summarize, circular economy can be defined from different aspects (ibid.). In its essence, it represents a global model of sustainable economic development in which resources are used moderately and reasonably (ibid.). From resource point-of-view, the model discriminates between biological and technical materials and results in prolonging the useful lifespan of both as much as possible (ibid.). In the pre-manufacturing phase, circular economy model requires that products are designed effectively and efficiently so as to enable their circular flow (ibid.). With regards to economic opportunities, it stimulates innovative approaches to all stages of product lifespan, and by providing all of the above, sets course for a new sustainable system (ibid.).

In Picture 1, the linear economy is clearly observable by its straightforward flow downwards, while circular economy is depicted in the form of loops, representing the bilateral flow of different materials (Webster 2017, 18). Circular economy diagram, as shown below, depicts three principles, or stages. The goal of the first stage is to retain and fortify natural capital by controlling the limited resources and harmonizing the renewable resource flows. The second stage focuses on improving profitability of resources through circulation of products, components, and materials being used. Its goal was to make the products, components, and materials as useful as possible in every phase of technological or natural cycle. The third stage in the diagram wishes to increase the system's efficiency by opening the system and re-structuring it in such way to avoid negative external expense. 
Picture 1: Circular Economy Diagram

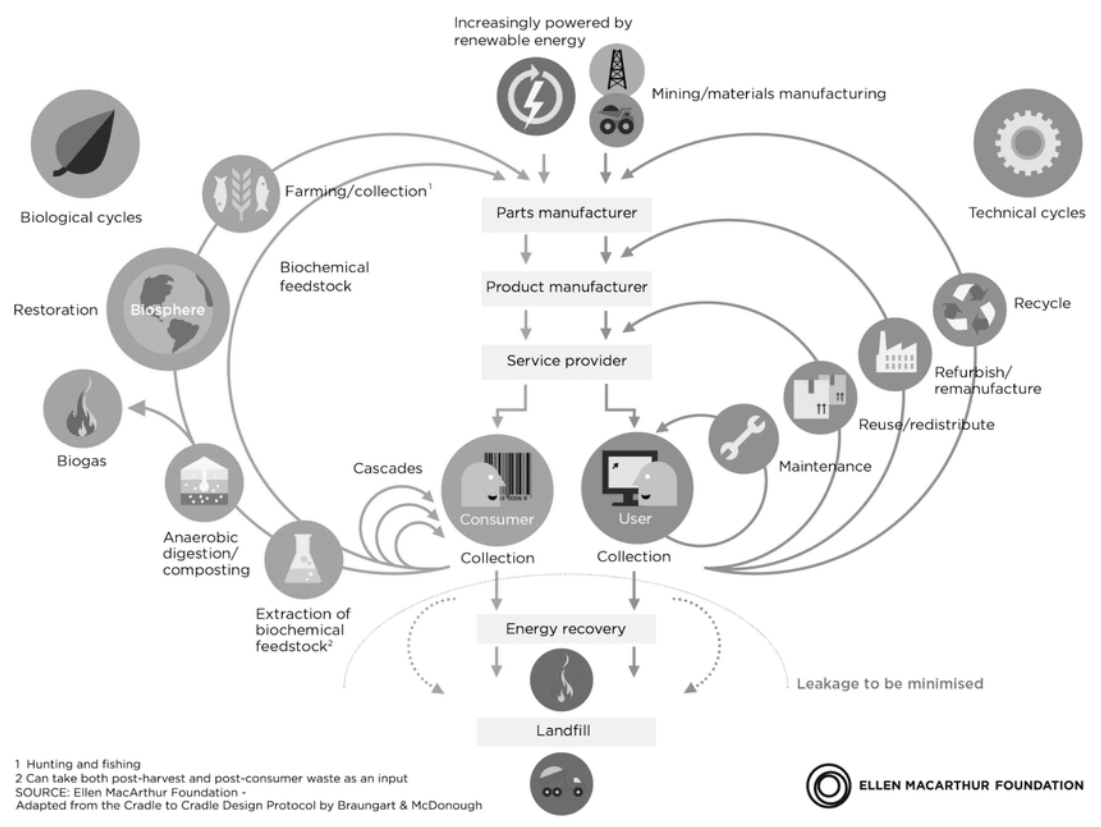

Source: Ellen MacArthur Foundation 2016

In the process of applying circular economy into practice, certain concepts are being put in place, which can be used as drivers for enforcement of circular economy. One of such drivers is Cradle-to-Cradle ${ }^{\circledR}$ which is a registered trademark of McDonough Braungart Design Chemistry, LLC (C2CCentre 2013; McDonough and Braungart 2013). Cradle-to-Cradle ${ }^{\circledR}$ Certified ${ }^{\mathrm{cm}}$ is a certification mark licensed exclusively for the Cradle-toCradle $^{\circledR}$ Products Innovation Institute (C2C-Centre 2013). Cradle-to-Cradle ${ }^{\circledR}$ used by EPEA ${ }^{1}$ in Switzerland since 1995, it ensures the quality of resources through its multiple lifecycles, whereas all resources must be manufactured from nontoxic materials and return to manufacturing process of the same social actor once their lifespan expires (ibid.). This concept is based on a

\footnotetext{
1 EPEA GmbH - Part of Drees \& Sommer (formerly EPEA Internationale Umweltforschung $\mathrm{GmbH}$, founded in 1987 by Dr. Michael Braungart) was founded in 2019 is an internationally active scientific research and consultancy institute we work with actors and companies from economy, politics and science and support them in the introduction of circular processes (EPEA 2019). EPEA combine different sciences: chemistry, biology and environmental science with product optimization and product development (ibid.).
} 
defining materials as belonging to biological or technical material (ibid.). While biological materials are biodegradable and result in natural decomposition, technical materials should be kept separately from biological materials and used in separate manufacturing processes (ibid.). Cradle-toCradle ${ }^{\circledR}$ concept defines all waste as food, necessitates the use of renewable energy sources, and supports diversity as fundamentally creative and resilient force driving the system (ibid.).

Founding Cradle-to-Cradle ${ }^{\circledR}$ principles include: (1) all materials flow in one of the two cycles: biological (can be safely decomposed through the biosphere) or technical (non-biodegradable, kept at high quality and away from the biosphere in their own industrial cycle); (2) everything is food (sometimes described as waste = food); (3) shift towards clean energy, essentially renewable; (4) celebrate diversity (since it is a source of both creativity and resilience in system (ibid.). In the following, we outline the key impacts of Cradle-to-Cradle ${ }^{\circledR}$ and support our assumptions by one of the most famous example of Cradle-to-Cradle ${ }^{\circledR}$ best practice - ECOVER professional ${ }^{\circledR}$.

In 2013 ECOVER professional ${ }^{\circledR}$, which is a pioneer in the development of powerful, ecological cleaning products, has developed its Ecover Professional range with three new products (C2C 2013). So impressive was the new range that it has been awarded a 'Cradle to Cradle Certified' title - a first in the world of professional cleaning - no other professional cleaning product can say the same (ibid.). After almost 20 years of providing professional cleaning products that pack a punch, this breakthrough in sustainability takes powerful, professional cleaning products to a new level (ibid.). The new Ecover Professional products are sold across Europe through the existing business to business dealer network to the public sector, the healthcare sector, the leisure sector and contract cleaners (ibid.). The formulas of Ecover professional products have been designed with a maximum of renewable ingredients - most products are composed of $95 \%$ or $99 \%$ renewable ingredients (ibid.). The Professional range's packaging bottles are made entirely from Plantastic PolyEthylene (PE), which is a revolutionary green plastic made from sugarcane that is $100 \%$ renewable, reusable and recyclable (ibid.). Their Plantastic bottles meets the Gold criteria in the category of material reutilization of Cradle to Cradle certification (ibid.). The most dangerous particles were found in the packaging of their cleaning products (ibid.). That is why Ecover Professional changed the caps of the bottles into transparent-coloured caps (ibid.). The ingredients of the cleaning agents are selected in that way to have an optimal biodegradability and a minimum impact on aquatic life (ibid.). Ecover Professional already uses $100 \%$ green energy for their electricity and they are also looking into the possibilities of 
biogas and works together with a local water purification company to clean their production water before going to nature (ibid.).

Re-use enables savings in the cost of raw materials and energy, and better long-term reliability in the supply of natural resources. Turning waste into resource is of key importance for circular economy, however the resources represent only part of the overall cycle. To make the cycle complete, these resources from one industry need to be processed and recycled to become raw material for another industry. Only in this case we can speak of the second driver of circular economy - industrial symbiosis - which has in the last two decades become an extremely important sustainable mechanism for recycling of waste and waste resources in industrial and non-industrial processes. We can therefore understand it as relationship between three or more social actors, which are linked through direct exchange of material, water, or energy waste, mostly in the form of scraps and by-products, while the exchanges between actors represent synergies (Rončević and Fric 2015). We are speaking about a flow of unexploited waste from one social actor, who was going to discard the waste, to the other social actor, who is able to use it as substitute for new/primary resources (Deutz 2014, 4). The synergies between social actors today are increasingly moving towards exchange of knowledge and logistics services as support and municipal services for exchange of waste resources. In this mutually-dependent relationship, each social actor reaches their own benefits and goals, while contributing to the welfare of other social actors and society in general (Manahan 1999, 58). Industrial symbiosis exists on local, regional, national and international levels. Chertow (2007) claims that geographical proximity of social actors is the pre-condition for implementation of industrial symbiosis. In other words: social actors involved in direct flow of secondary material resources must be located nearby. However, this depends on economics of specific exchange, linked with logistical costs. Furthermore, social actors taking part in industrial symbiosis network, but who are not directly involved in material flows, geographical proximity is not as important, especially due to recent development of Information Communication Technology tools for management of industrial symbiosis. Next, we outline the key impacts of industrial symbiosis and support our assumptions by one of the most famous example of industrial symbiosis best practice - Kalundborg.

Kalundborg case study is considered one of the earliest and most famous examples of best practice in industrial symbiosis in the world. Kalundborg is a small harbor town on the northwest coast of the largest Danish island of Sjælland in Denmark. The case study began in 1961 as water management project (Ehrenfeld and Gertler, 1997). Because supply of fresh water in 
Zealand region, where Kalundborg is located, was not always available, the local authorities decided to install a pipeline for the new refinery to provide the refinery with water intake from Lake Tissø (ibid.). In 1981, Asnæs thermal power plant began supplying Kalundborg with steam for heating new neighborhoods (ibid.). Soon afterwards, the system was extended to Statoil and Novo Nordisk towns (ibid.). The steam-driven heating system from the thermal power plant had replaced about 3,500 oil furnaces, which would otherwise have represented a significant source of air pollution (ibid.). The thermal power plant uses sea water for cooling, thus reducing the use of fresh water from Lake Tissø (ibid.). The plant feeds part of the hot salty water, which is produced as a by-product in the process of cooling, into 57 ponds of the nearby fish farm (ibid.). Consumption of fresh water for cooling is also reduced by using pre-treated water, which is supplied by Statoil oil refinery and amounts to approx. 1 million cubic meters of water per year (ibid.). In turn, the refinery supplies its excess gas to Gyproc company - after observing a flame at the top of the refinery and the burning gas, the company quickly identified it as a potentially cheap source of energy (ibid.). Novo Nordisk pharmaceutical company sells biomass, produced as by-product in their industrial process, to local farmers to be used as fertilizer (ibid.).

These best practices are not best practices due to some revolutionary technological development and legislative and legal framework which brought about a new approach. If this was the case, dissemination of technology would suffice for rapid development throughout the world. Instead they exemplify that formation of well-functioning circular economy is primarily dimension of the social aspect. Other research based on sustained development without including "sustainability" (environmental) dimension (Adam et al. 2005) and on multi-criteria decision modeling of successful cases demonstrated definitively that social factors, alongside technological and economic aspects (Mileva Boshkoska et al. 2018), play important role in establishment of successful circular economy. This should not come as a surprise, since we have demonstrated the impact of social factors on other aspects of technological innovations (Modic and Rončević 2018; Rončević and Modic 2012), and applicability of this line of analysis in others (Fric and Rončević 2018) however, in research on circular economy this perspective is poorly developed and worthy for further research.

In 2018 have been drafted the case studies as part of a study funded by the EC, on "Cooperation for Industrial Symbiosis: Policy Aactions and good Practice", performed by a consortium led by Technopolis Group in partnership with UCL (Univeristy College London), Trinomics B.V., TNO and International Synergies (UCL and Technopolis Group 2018). In this study with 
the title "Cooperation fostering Industrial Symbiosis: Market potential, good Practice and Policy Actions", the types of industrial symbiosis that are being analysed included two crucial groups: (1) self-organised activity, emerging as the result of direct interaction among different social actors, without any topdown coordination; (2) managed networks, those that have a third party intermediary that coordinates the activity (Baas 2011 in ibid.). Two distinct types of managed networks exist: (1) facilitated networks, working with existing companies to raise awareness of industrial symbiosis and foster activity and (2) planned networks, where the networks are formed following a central plan or vision that includes attracting new businesses to purposebuilt developments, generally offering shared infrastructures and services (ibid.). Industrial symbiosis networks contain different social actors belonging to different sectors of activity that engage in mutually beneficial transactions of waste and by-products - materials, energy, water, capacity, expertise, assets etc. (ibid.). Industrial symbiosis has been seen as a solution to enhance environmental sustainability and achieve economic benefits at the same time (ibid.). As state UCL and Technopolis Group (2018) while there are cases of successful implementation of industrial symbiosis, there is still little overview of the market for industrial symbiosis, and the scale at which it has been adopted. Moreover, the importance of intermediary bodies as facilitators of industrial symbiosis has only just begun to be considered as a crucial factor for the success of industrial symbiosis initiatives (ibid.). In this study, UCL and Technopolis Group aim to provide an overview of the market potential for industrial symbiosis and a mapping of the major initiatives that have been implemented in Europe and their results (ibid.).

\section{Status Quo: EC delivers on Action Plan of Circular Economy}

In 2019 EC announced a summary of activities in "Circular Economy Action Plan". As reported EC 54 actions under the mentioned plan launched in 2015 have now been delivered or are being implemented (European Commision Press release 2019). This status quo are going to contribute to boost Europe's competitiveness, modernise its economy and industry to create jobs, protect the environment and generate sustainable growth (ibid.).

The EC in march 2019 published a comprehensive report on the implementation of the "Circular Economy Action Plan" it adopted in 2015 (ibid.). This report presents the crucial results of implementing the "Circular Economy Action Plan" and sketches out open challenges to paving the way towards a climate-neutral, competitive circular economy where pressure on natural and freshwater resources as well as ecosystems is minimised (ibid.). 
Three years after adoption, the "Circular Economy Action Plan" can be considered fully completed, states EC (ibid.). According to the findings of the report, implementing the "Circular Economy Action Plan" has accelerated the transition towards a circular economy in Europe, which in turn has helped putting the EU back on a path of job creation (ibid.). EC continues that in 2016, sectors relevant to the circular economy employed more than four million workers, a 6\% increase compared to 2012 (ibid.). Circular economy has also opened up new business opportunities, given rise to new business models and developed new markets, domestically and outside the EU - in 2016, activities such as repair, reuse or recycling generated almost $€ 147$ billion in value added while accounting for around $€ 17.5$ billion worth of investments (ibid.).

EC states also that the EU "Strategy for Plastics in a Circular Economy" is the first EU-wide policy framework adopting a material-specific lifecycle approach to integrate circular design, use, re-use and recycling activities into plastics value chains (ibid.). This strategy sets out a clear vision with quantified objectives at EU level, so that inter alia by 2030 all plastic packaging placed on the EU market is reusable or recyclable (ibid.). For boosting the market for recycled plastics, the EC launched a voluntary pledging campaign on recycled plastics (ibid.). Approximately 70 companies have already made pledges, which are going to increase the market for recycled plastics by at least $60 \%$ by 2025 - there is still a gap between supply and demand for recycled plastics (ibid.). For closing this gap, the EC launched the "Circular Plastics Alliance" of key industry stakeholders supplying and using recycled plastics (ibid.). EC emphasizes also that the rules on "SingleUse Plastics" items and fishing gear, addressing the most found items on EU beaches place the EU at the forefront of the global fight against marine litter (ibid.). The measures include a ban of certain single-use products made of plastic (straws and cutlery for exmaple) when alternatives are available and of oxo-degradable plastic, and propose actions for others such as consumption reduction targets, product design requirements and "Extended Producers Responsibility Schemes" (ibid.).

EC notes that to accelerate the transition to a circular economy, it is essential to investin innovation and to provide support for adapting Europe's industrial base (ibid.). Over the period 2016-2020, the EC has stepped up efforts in both directions totalling more than $€ 10$ billion in public funding to the transition (ibid.). For stimulating further investments, the "Circular Economy Finance Support Platform" has produced recommendations to improve the bankability of circular economy projects, coordinate funding activities and share best practices (ibid.). The platform are going to work with the European Investment Bank on providing financial assistance and 
exploiting synergies with the "Circular Economy Action Plan" on financing sustainable growth (ibid.).

EC adds that sound and efficient waste management systems are an essential base of a circular economy (ibid.). For modernising waste management systems in the EU a revised waste legislative framework entered into force in 2018 (ibid.). The revised waste legislative framework includes new ambitious recycling rates, clarified legal status of recycled materials, strengthened waste prevention and waste management measures, including for marine litter, food waste, and products containing critical raw materials (ibid.).

The most important in this process is also smart design at the beginning of a product's lifecycle is essential for ensuring circular economy (ibid.). Through the implementation of the "Ecodesign Working Plan 2016-2019", the EC has further promoted the circular design of products, together with energy efficiency objectives (ibid.). Ecodesign and Energy Labelling measures for several products now include rules on material efficiency requirements availability of spare parts, ease of repair, and facilitating end-of-life treatment (ibid.). The EC has also analysed, in a dedicated "Staff Working Document", its policies for products, with the intention to support circular, sustainable products (ibid.).

For transition towards a more circular economy requires an active engagement of citizens in changing consumption patterns (ibid.). The Product Environmental Footprint (PEF) and Organisation Environmental Footprint (OEF) methods developed by the EC can enable companies to make environmental claims that are trustworthy and comparable and consumers to make informed choices (ibid.).

For the transition is also the most important engagement (ibid.). The systemic approach of the action plan has given public authorities, economic and social actors and civil society a framework to replicate in order to foster partnerships across different sectors (ibid.). The role of the EC in speeding up the transition and leading international efforts for circularity was also recognised at the World Economic Forum 2019 where the EC received the "Circulars Award in the Public Sector Category" (ibid.).

This implies that actual efforts for transition from linear to circular economy can be explained in part, as well as interpreted in terms of semiosis which is the umbrella term for diferent approaches to the cultural turn insofar as they assume both that semiosis is causally efficacious as well as meaningful (Jessop and Osterlynck 2008). CPE namely studies the role of semiotic activities and practicies not only in the continual (re-)making of social relations but also in the contingent emergence (variation), privileging 
(selection), ongoing realization (retention), and subsequent reinforcement through structural coupling (consolidation) of their extra-semiotic properties (ibid.). As discussed Jessop and Osterlynck (2008) the same basic mechanisms serve to select and consolidate radically new practices - drivers of circular economy for transition from linear to circular economy and to stabilize routine practices - culture and political engagement towards to a circular economy.

\section{Conclusion}

As notes EC the circular economy is now an irreversible, global trend - yet, much is still needed to scale up action at EU level and globally, fully close the loop and provide the competitive advantage it brings to EU economy (European Commision - Press release 2019). Increased efforts are going to be needed to implement the revised waste legislation and develop markets for secondary raw materials (ibid.). Also, the work started at EU level on some issues (chemicals, the non-toxic environment, eco-labelling and ecoinnovation, critical raw materials and fertilisers for the exmaple) needs to be accelerated if Europe wants to reap the full benefit of a transition to a circular economy also still EC notes (ibid.).

Interaction with different stakeholders and social actors suggests that some areas not yet covered by the "Circular Economy Action Plan" could be investigated to complete the circular agenda (ibid.). Building on the example of the "European Strategy for Plastics in a Circular Economy", many other sectors with high environmental impact and potential for circular economy such as information technology (IT), electronics, mobility etc., the built environment, mining, furniture, food and drinks or textiles could benefit from a similar holistic approach to become more circular (ibid.).

Last but not least there is reasonable to add policy makers for faster transition from linear to circular economy should follow some recommendations of CPE. As state Jessop and Osterlynck (2008) the most important in this process are the following recommendations: (1) to consider with cultural studies as a whole and not just with one preferred theorist or institution in the area under consideration and (2) to engage the complexities of semiosis and explore the discursive and material mechanisms that shape the manner and extent to which 'ideas matter' in political economy. 


\section{References}

Adam, Frane, Makarovič, Matej, Roncević, Borut and Tomšič, Matevž. 2005. The Challenges of Sustained Development: The Role of Socio-cultural Factors in East-Central Europe. New York, Budapest: CEU Press.

Barbero, Silvia. 2017. Systemic Design Method Guide for Policymaking. A Circular Europe on the Way. Torino: Umberto Allemandi Srl.

C2C-Centre. 2013. World first: First impact measurement Cradle to Cradle. http://www.c2c-centre.com/news/world-first-first-impactmeasurementcradle-cradle. Accessed April 8, 2019.

Chertow, Marian Ruth. 2007. “'Uncovering” Industrial Symbiosis.” Journal of Industrial Ecology 11 (1): 11-26.

Cradle to Cradle Products Innovation Institute. 2013. 2013 Innovation Stories. https://www.troldtekt.com/ /media/Files/Articles\%20and\%20books/Tro ldtekt_C2C_Your\%20Innovation\%20Stories\%20Book\%20pdf.pdf. Accessed April 8, 2019.

De Angelis, Roberta. 2018. Business Models in the Circular Economy. Concepts, Examples and Theory. Cham: Palgrave Pivot.

Deutz, Pauline. 2014. "Food for Thought: Seeking the Essence of Industrial Symbiosis." In Pathways to Environmental Sustainability Methodologies and Experiences, ed. Roberta Salomone R. in Giuseppe Saija, 3-13. Cham: Springer.

Ehrenfeld, John and Gertler Nicholas. 1997. "Industrial Ecology in Practice: The Evolution of Interdependence at Kalundborg." Journal of Industrial Ecology 1(1): 67-80.

Ellen MacArthur Foundation. Circular Economy Overview. 2016. https://www.ellenmacarthurfoundation.org/circulareconomy/overview/concept. Accessed April 8, 2019.

Ellen MacArthur Foundation. Circular Economy Overview. 2017. https://www.ellenmacarthurfoundation.org/circulareconomy/overview/concept. Accessed April 8, 2019. 
EPEA PART OF DRESS AND SOMMER. 2019. About us. https://epeahamburg.com/about/. Accessed April 8, 2019.

EUR-Lex. Access to European Law. 2008. Directive 2008/98/EC of the European Parliament and of the Council of 19 November 2008 on waste and repealing certain Directives. http://eur-lex.europa.eu/legal-content/ EN/TXT/PDF/?uri=CELEX:32008L0098\&from=EN. Accessed April 8, 2019.

EUR-Lex. Access to European Law. 2014. Communication from the Commission to the European Parliament, the Council, the European Economic and Social Committee and the Committee of the Regions towards a Circular Economy: A Zero Waste Programme for Europe. http://eurlex.europa.eu/legalcontent/EN/TXT/PDF/?uri= CELEX:52014DC0398\&from=EN. Accessed April 8, 2019.

EUR-Lex. Access to European Law. 2015. Communication from the Commission to the European Parliament, the Council, the European Economic and Social Committee and the Committee of the Regions Closing the Loop: An EU Action Plan for the Circular Economy. http://eur-lex.europa.eu/legalcontent/EN/TXT/?uri=

CELEX:52015DC0614. Accessed April 8, 2019.

European Commission. 2019. Circular Economy. Implementation of the Circular Economy Action Plan. https://ec.europa.eu/environment/circulareconomy/index_en.htm. Accessed April 8, 2019.

European Commission. 2019. Closing the Loop: Commission delivers on Circular Economy Action Plan.

https://europa.eu/rapid/press-release_IP-19-1480_en.htm. Accessed April 8, 2019.

European Commission. 2019. What is Horizon 2020? https://ec.europa.eu/programmes/horizon2020/what-horizon-2020. Accessed April 8, 2019.

Fric, Urška and Rončević, Borut. 2018. "E-Simbioza: Leading the Way to a Circular Economy through Industrial Symbiosis in Slovenia." Socijalna ekologija 27 (2): 119-140. 
Jessop, Bob and Oosterlynck, Stijn. 2008. "Cultural Political Economy: On Making the Cultural Turn without Falling into Soft Economic Sociology." Geoforum 39 (2008): 1155-1169.

Manahan, Stanley E. 1999. Industrial Ecology: Environmental Chemistry and Hazardous Waste. CRC Press LLC.

McDonough, William and Braungart, Michael. 2013. The Upcycle. Beyond Sustainability - Designing for Abundance. New York: North Point Press.

Mileva Boshkoska, Biljana, Rončević, Borut and Uršić Džajić, Erika. 2018. "Modeling and Evaluation of the Possibilities of Forming a Regional Industrial Symbiosis Networks." Social Sciences 7 (1): 1-26.

Ministry of Economic Development and Technology Republic of Slovenia. 2013. Strategija pametne specializacije 2014-2020. http://www.mgrt.gov.si/si/delovna_podrocja/evropska_kohezijska_politika/ razvojno_nacrtovanje_in_programiranje_strateskih_in_izvedbenih_dokument ov/strategija_pametne_specializacije_2014_2020/. Accessed April 8, 2019.

Modic, Dolores and Rončević, Borut. 2012. "Social Topography for Sustainable Innovation Policy: Putting Institutions, Social Networks and Cognitive Frames in their Place." Comparative sociology 17 (1): 100-127.

Razvojna agencija ROD. SPOT novice 3 - Prehod v krožno gospodarstvo. http://ra-rod.si/2018/07/23/prehod-v-krozno-gospodarstvo/. Accessed April 9, 2019.

Rončević, Borut and Fric, Urška. 2015. "Researching Industrial Symbiosis: Challenges and Dilemmas." In Applied Modelling and Computing in Social Science, edited by Janez Povh. Frankfurt am Main: PL Academic Research, pp. 35-49.

Rončević, Borut and Modic, Dolores. 2012. "Social Fields of Technological Innovations." In Global Trends and Regional Developmentm edited by Nikolai Genov. New York: Routledge, pp. 226-247.

UCL and Technopolis Group (2018). Cooperation for Industrial Symbiosis: market potential, good practice and policy actions. Good practice case studies. Funded by the European Commission, DG GROW, Brussels. 
https://publications.europa.eu/en/publication-detail//publication/174996c9-3947-11e8-b5fe-01aa75ed71a1/language-en. Accessed April 10, 2019.

World Health Organization (WHO). 2016. A Healthy Link: The Protocol on Water and Health and the Sustainable Development Goals. https://www.unece.org/fileadmin/DAM/env/water/mop4/Informal_doc/1 623151_E_FinalWEB_rev.pdf. Accessed April 12, 2019. 